\title{
Prevalence of atopy and asthma in overweight children and adolescents - a cross-sectional study
}

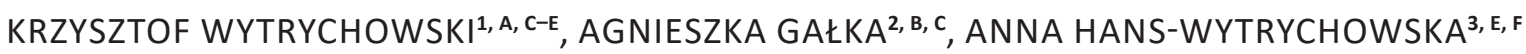 \\ ${ }^{1}$ Department and Clinic of Internal Medicine and Allergology, Wroclaw Medical University, Poland \\ ${ }^{2}$ Student, Wroclaw Medical University, Poland \\ ${ }^{3}$ Department of Family Medicine, Wroclaw Medical University, Poland
}

A - Study Design, B - Data Collection, C - Statistical Analysis, D - Data Interpretation, E - Manuscript Preparation, F - Literature Search, G - Funds Collection

\begin{abstract}
Summary Background. A steady growth in the prevalence of asthma and overweight in children has been observed over the last three decades. There is a lot of evidence that obesity in children is a risk factor in the development of asthma.

Objectives. We examined the relationship between obesity and development of atopy and asthma in children aged 6-18.

Material and methods. A cross-sectional study was performed based on the medical records of 175 children and adolescents treated at the allergology outpatient clinic with diagnosed atopic diseases. From the same age population of patients of the general medicine clinic, the medical records of 207 children and adolescents were randomly chosen as a control group. In study group, atopy was confirmed with the use of skin prick tests or the measurement of specific IgE antibodies. The weight, height and BMI were determined for all the studied children. Both groups were divided into subgroups of younger children ( $\leq 12$ years) and adolescents (>12 years). Results. In both groups, overweight children (BMI > 25; $>85^{\text {th }}$ percentile) were identified. The groups were uniform as regards gender, age and BMI. The percentage of overweight children was greater in the group with atopy than in the control group (14.3\% vs $5.3 \%$; $p=0.043)$. In the groups $\leq 12$ and $>12$, the percentage of overweight and obese children was higher in the group with atopy than in the control group, but the difference was statistically insignificant $(p=0.142$ and $p=0.061$, respectively). In the group with atopy, the number of overweight children suffering from asthma was significantly smaller in the group of younger children than in the group of older children $(7.4 \%$ vs $20.2 \% ; p=0.028)$. In the group with atopy, there were 148 children with correct body weight, out of which 2 children (1.3\%) were diagnosed with asthma. 23 out of 25 overweight children (92\%) were diagnosed with asthma $(p<0.001)$.

Conclusions. In the studied population of children and adolescents with atopic diseases, the prevalence of overweight was greater compared with their healthy peers. Bronchial asthma is an atopic disease connected with a high prevalence of overweight and obesity in the studied subjects.

Key words: obesity, bronchial asthma, children and adolescents.
\end{abstract}

Wytrychowski K, Gałka A, Hans-Wytrychowska A. Prevalence of atopy and asthma in overweight children and adolescents - a cross-sectional study. Fam Med Prim Care Rev 2017; 19(3): 283-288, doi: https://doi.org/10.5114/fmpcr.2017.69292.

\section{Background}

Bronchial asthma is the most common chronic disease in children. Asthma is a heterogenic disease with many phenotypes, depending on the clinical course, demographics and pathophysiology. One of its phenotypes is asthma connected with obesity. Bronchial asthma is the main cause of morbidity in children in the USA [1]. A steady growth in the prevalence of asthma has been observed over the last three decades and has been attributed to the following: air pollution, smoking, lower exposure to infections. At the same time, a growth in the rate of overweight in children has been observed in developed countries [2]. According to American data, 25.7 million people suffer from bronchial asthma in the USA, and 35.7 percent of the total population in the USA suffer from obesity [3]. The prevalence of overweight in children aged $6-11$ in the USA has been found to be $15.3 \%$, and in the group aged $12-19$, it is $15.5 \%$ [4]. The connection between overweight and asthma both in children and adults has been confirmed [5]. There are a lot of mechanisms responsible for this connection: diet (long chain fatty acids,) gastroesophageal reflux, hormonal disorders, breathing disorders and chronic systemic inflammation [6].

The prevalence of overweight among US children increased more than 10\% between 1988-1994 and 1999-2000 [7]. The population attributable risk of future asthma in children was estimated at 0.066 , which means that $6.6 \%$ of newly diagnosed cases of asthma in childhood are related to overweight. The conducted meta-analysis demonstrated that a high weight at birth increases the risk of the development of asthma by $20 \%$ (RR 1.2; 95\% Cl 1.1-1.3), whereas overweight in children increases the risk of the development of asthma by $50 \%$ (RR 1.5; $95 \% \mathrm{Cl} 1.2-1.8)$. It is estimated that about 100,000 children in the USA suffer from asthma caused by overweight [8]. A European study demonstrated that a rapid growth in body mass in the first two years of life increases the risk of the development of asthma by the age of six in children with low body mass at birth [9]. The allergic phenotype of asthma occurs more often in overweight children compared to their peers with correct body mass, along with a growth in the prevalence of atopic diseases - allergic rhinitis and atopic dermatitis [10]. Overweight has been proven to be a risk factor in the development of asthma in young children, whereas overweight and obesity in adolescents and adults significantly deteriorates the course of previously diagnosed asthma [11]. The prevalence of asthma and obesity has been growing over the last few decades in all age groups, but the greatest rate of growth of both diseases has been observed in children and adolescents. The problem of overweight especially affects the population of children in Poland. A comparison 
of the same population at the age of 14-16 in 2005 (655 subjects) and then in 2014 (438 subjects) demonstrated a growth in incorrect body weight (BMI > 25) from $11 \%$ to $22 \%(p<0.01)$ [12]. An OLAF study of 17,000 children and adolescents aged 7-18 demonstrated an incorrect body weight in $18 \%$ of boys and $14 \%$ of girls. This was confirmed by the UNICEF report from 2013 titled The conditions and the quality of life of children in the developed countries. Comparative analysis, which demonstrates that the number of overweight children aged 11,13 and 15 doubled in Poland over the last decade. This was the greatest growth in all countries included in the analysis (19 European countries, as well as the USA and Canada) [13].

\section{Objectives}

We examined the relationship between obesity and the prevalence of atopy and asthma in children aged 6-18.

\section{Material and methods}

At the allergology clinic in Oleśnica, Poland, the medical records of 175 patients aged 6-18 (group S) were selected from the total population of adults and children on the basis of ICD-10 numbers of the most common atopic diseases: J45, J45.9, J30.1, J30.2, J30.3, J30.4, L50, L20, L20.8, L20.9, L23 (bronchial asthma, allergic rhinitis, utricaria, atopic dermatitis, allergic contact dermatitis). Group S consisted of 77 girls (44\%) and 98 boys (56\%). Atopy was confirmed in all patients via skin prick tests (Allergopharma $\mathrm{GmbH}$, Germany), in compliance with applicable procedures [14], or by establishing the presence of specific IgE antibodies (ImmuCAP/Pharmacia, Pharmacia Diagnostics $A B$, Sweden). Height and weight were measured with the use of the WPT 60/150 OW (RADWAG, Poland) electronic weight scale with height measurement.

Out of 3,550 children assigned to 3 Primary Health Care clinics ( 2 in Oleśnica, 1 in Bierutów), the medical records of 207 children aged 6-18 were selected randomly to group C (control).
Group C consisted of 90 girls (43.5\%) and 117 boys (56.5\%). Patients with the above-mentioned ICD-10 were excluded from the control group, and for randomization, a random number generator (losowe.pl) was used. Number of 207 randomly chosen patients guaranteed power test calculation for 0.8 by $p$-value 0.05 .

The weight and height, as well as BMI, were measured in all children. The BMI was compared against the percentile for children of the same gender and age according to tables for the Polish population [15]. A BMI less than the $5^{\text {th }}$ percentile was considered underweight, and a $\mathrm{BMI}$ above the $95^{\text {th }}$ percentile was considered obese. Children with a BMI between the $85^{\text {th }}$ and $95^{\text {th }}$ percentile were considered to be overweight.

\section{Statistical analyses}

Quantitative variables are shown as mean (M), standard deviations (SD), median (Me), lower quartiles (Q1), upper quartiles (Q3) and extreme values (min, max). In the statistical analysis, the Shapiro-Wilk's W test and the Mann-Whitney U test were used for quantitative variables. Qualitative variables are shown in the tables as cardinality $(n)$ and proportion (\%). For qualitative variables for $2 \times 2$ tables, Yates's chi-squared test or Fisher's exact two-tailed test were used. Empirical distribution of age and BMI differed significantly from theoretical normal distribution and for these two variables, Kolmogorov-Smirnov and Lilliefors test for normality by $p<0.05$ was used. Calculations were performed using STATISTICA software (StatSoft Inc., Tulsa, OK, USA).

\section{Results}

In group S, 25 patients were diagnosed with asthma and, additionally, allergic rhinitis. The other patients from group $S$ were diagnosed with allergic rhinitis (87 patients), atopic dermatitis (13), urticaria (15) and allergic contact dermatitis (8). Some patients were diagnosed with more than one atopic disease: allergic rhinitis with atopic dermatitis (20) and urticaria with contact dermatitis (7). The average age in group $S$ was 12.6 years \pm

\begin{tabular}{|c|c|c|c|c|c|c|c|}
\hline \multirow{2}{*}{$\begin{array}{l}\text { Feature (variable) } \\
\text { Gender: }\end{array}$} & \multicolumn{2}{|c|}{$\begin{array}{l}\text { Study group (S) } \\
(n=175)\end{array}$} & \multicolumn{2}{|c|}{$\begin{array}{l}\text { Control group (C) } \\
(n=207)\end{array}$} & \multicolumn{2}{|c|}{$\begin{array}{l}\text { Total } \\
(n=382) \\
\end{array}$} & \multirow{4}{*}{\begin{tabular}{|l}
$\begin{array}{l}\text { Test result } \\
\text { (S vs C) }\end{array}$ \\
$p=0.999$
\end{tabular}} \\
\hline & $n$ & $\%$ & $n$ & $\%$ & $n$ & $\%$ & \\
\hline Female (F) & 77 & $44 \%$ & 90 & $43.5 \%$ & 167 & $43.7 \%$ & \\
\hline Male (M) & 98 & $56 \%$ & 117 & $56.5 \%$ & 215 & $56.3 \%$ & \\
\hline \multicolumn{7}{|l|}{ Age [years]: } & \multirow{4}{*}{$p=0.204$} \\
\hline$M \pm S D$ & \multicolumn{2}{|c|}{$12.6 \pm 3.5$} & \multicolumn{2}{|c|}{$12.1 \pm 3.6$} & \multicolumn{2}{|c|}{$12.3 \pm 3.6$} & \\
\hline $\operatorname{Me}\left[Q_{1} ; Q_{3}\right]$ & \multicolumn{2}{|c|}{$13[9 ; 15]$} & \multicolumn{2}{|c|}{$12[9 ; 15]$} & \multicolumn{2}{|c|}{$13[9 ; 15]$} & \\
\hline Min-max & \multicolumn{2}{|c|}{$6-18$} & \multicolumn{2}{|c|}{$6-18$} & \multicolumn{2}{|c|}{$6-18$} & \\
\hline \multicolumn{7}{|l|}{$\mathrm{BMI}\left[\mathrm{kg} / \mathrm{m}^{2}\right]$} & \multirow{4}{*}{$p=0.123$} \\
\hline $\mathrm{M} \pm \mathrm{SD}$ & \multicolumn{2}{|c|}{$19.6 \pm 3.9$} & \multicolumn{2}{|c|}{$18.9 \pm 3.5$} & \multicolumn{2}{|c|}{$19.2 \pm 3.7$} & \\
\hline $\operatorname{Me}\left[Q_{1} ; Q_{3}\right]$ & \multicolumn{2}{|c|}{$19.1[16.9 ; 21.8]$} & \multicolumn{2}{|c|}{$18.8[16.2 ; 21.2]$} & \multicolumn{2}{|c|}{$18.9[16.5 ; 21.3]$} & \\
\hline Min-max & \multicolumn{2}{|c|}{$13.2-30.4$} & \multicolumn{2}{|c|}{$10.2-32.3$} & \multicolumn{2}{|c|}{$10.2-32.3$} & \\
\hline Age group [years]: & $n$ & $\%$ & $n$ & $\%$ & $n$ & $\%$ & \multirow{8}{*}{$p=0.043$} \\
\hline$\leq 12$ & 81 & $46.3 \%$ & 104 & $50.2 \%$ & 185 & $48.4 \%$ & \\
\hline$>12$ & 94 & $53.7 \%$ & 103 & $49.8 \%$ & 197 & $51.6 \%$ & \\
\hline \multicolumn{7}{|l|}{ BMI [percentile]: } & \\
\hline$<18.5\left(<5^{\text {th }} \mathrm{P}\right)$ & 13 & $7.4 \%$ & 19 & $9.2 \%$ & 32 & $8.4 \%$ & \\
\hline $18.5-24.9\left(5^{\text {th }} \leq \mathrm{BMI} \leq 85^{\text {th }} \mathrm{P}\right)$ & 110 & $62.9 \%$ & 145 & $70.0 \%$ & 255 & $66.8 \%$ & \\
\hline $25-29.9\left(85^{\text {th }} \mathrm{P}<\mathrm{BMI} \leq 95^{\text {th }} \mathrm{P}\right)$ & 27 & $15.4 \%$ & 31 & $15.0 \%$ & 58 & $15.2 \%$ & \\
\hline$>30\left(\mathrm{BMI}>95^{\text {th }} \mathrm{P}\right)$ & 25 & $14.3 \%$ & 12 & $5.8 \%$ & 37 & $9.7 \%$ & \\
\hline \multicolumn{7}{|l|}{ Asthma: } & \multirow{3}{*}{$p<0.001$} \\
\hline Yes & 25 & $14.3 \%$ & 0 & $0 \%$ & 25 & $6.5 \%$ & \\
\hline No & 150 & $85.7 \%$ & 207 & $100 \%$ & 357 & $93.5 \%$ & \\
\hline
\end{tabular}




\section{Studied group $S$}

Pearson's chi-squared test

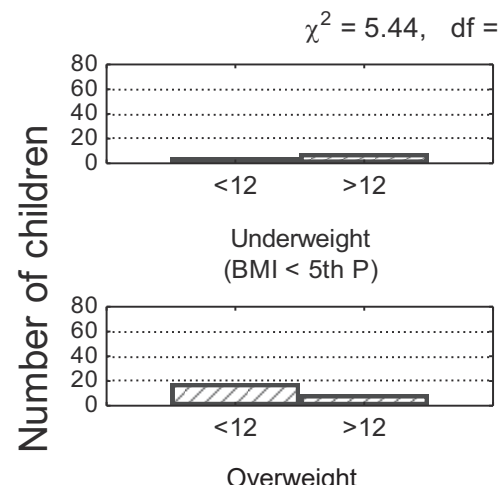

(85th $\mathrm{P}<\mathrm{BMl}<$ 95th $\mathrm{P}$ )

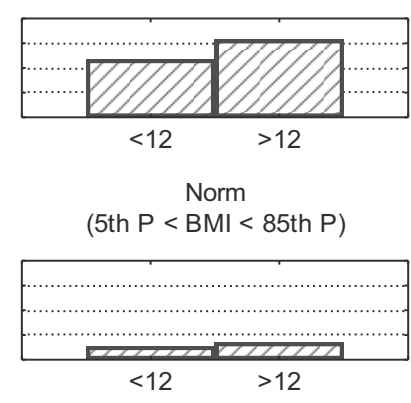

Obesity

$(\mathrm{BMI}>95$ th $\mathrm{P})$

Age (years)

Figure 1. Number of children in subgroups with different atopy status and BMI and the result of independence test

Group S - patients with atopy; BMI - body mass index; $\mathrm{P}$ - percentile; $<12$ - children up to12 years old; > 12 - children over 12

\begin{tabular}{|c|c|c|c|c|c|c|c|c|c|c|}
\hline \multirow[t]{3}{*}{ BMI [percentile] } & \multicolumn{5}{|c|}{$\begin{array}{l}\text { Study group (S) } \\
(n=175)\end{array}$} & \multicolumn{5}{|c|}{$\begin{array}{l}\text { Control group (C) } \\
(n=207)\end{array}$} \\
\hline & \multicolumn{2}{|c|}{$\begin{array}{l}\text { Age } \leq 12 \\
(n=81)\end{array}$} & \multicolumn{2}{|c|}{$\begin{array}{l}\text { Age }>12 \\
(n=94)\end{array}$} & \multirow[t]{2}{*}{$p$} & \multicolumn{2}{|c|}{$\begin{array}{l}\text { Age } \leq 12 \\
(n=104) \\
\end{array}$} & \multicolumn{2}{|c|}{$\begin{array}{l}\text { Age }>12 \\
(n=103) \\
\end{array}$} & \multirow[t]{2}{*}{$p$} \\
\hline & $n$ & $\%$ & $n$ & $\%$ & & $n$ & $\%$ & $n$ & $\%$ & \\
\hline $\mathrm{BMI}<5^{\text {th }} \mathrm{P}$ & 11 & 6.0 & 21 & 10.7 & \multirow{3}{*}{0.142} & 6 & 5.8 & 13 & 12.6 & \multirow{3}{*}{0.351} \\
\hline $5^{\text {th }} \mathrm{P} \leq \mathrm{BMI} \leq 85^{\text {th }} \mathrm{P}$ & 123 & 66.5 & 132 & 67.0 & & 76 & 73.1 & 69 & 67.0 & \\
\hline $85^{\text {th }} \mathrm{P}<\mathrm{BMI} \leq 95^{\text {th }} \mathrm{P}$ & 33 & 17.8 & 25 & 12.7 & & 15 & 14.4 & 16 & 15.5 & \\
\hline$>30\left(\mathrm{BI}>95^{\text {th }} \mathrm{P}\right)$ & 18 & 9.7 & 19 & 9.6 & & 7 & 6.7 & 5 & 4.9 & \\
\hline
\end{tabular}

\begin{tabular}{|c|c|c|c|c|c|c|c|c|c|c|}
\hline \multirow[t]{3}{*}{ BMI $\left[\mathrm{kg} / \mathrm{m}^{2}\right]$} & \multicolumn{5}{|c|}{$\begin{array}{l}\text { Age } \leq 12 \\
(n=185)\end{array}$} & \multicolumn{5}{|c|}{$\begin{array}{l}\text { Age }>12 \\
(n=197) \\
\end{array}$} \\
\hline & \multicolumn{2}{|c|}{$\begin{array}{l}\text { Study group S } \\
\text { ( } n=81)\end{array}$} & \multicolumn{2}{|c|}{$\begin{array}{l}\text { Control group C } \\
(n=104)\end{array}$} & \multirow[t]{2}{*}{$p$} & \multicolumn{2}{|c|}{$\begin{array}{l}\text { Study group S } \\
(n=94)\end{array}$} & \multicolumn{2}{|c|}{$\begin{array}{l}\text { Control group C } \\
(n=103)\end{array}$} & \multirow[t]{2}{*}{$p$} \\
\hline & $n$ & $\%$ & $n$ & $\%$ & & $n$ & $\%$ & $n$ & $\%$ & \\
\hline $\mathrm{BMI}<5^{\text {th }} \mathrm{P}$ & 5 & 6.2 & 6 & 5.8 & \multirow{4}{*}{0.150} & 8 & 8.5 & 13 & 12.6 & \multirow{4}{*}{0.063} \\
\hline $5^{\text {th }} \mathrm{P} \leq \mathrm{BMI} \leq 85^{\text {th }} \mathrm{P}$ & 47 & 58.0 & 76 & 73.1 & & 63 & 67.0 & 69 & 67.0 & \\
\hline $85^{\text {th }} \mathrm{P}<\mathrm{BMI} \leq 95^{\text {th }} \mathrm{P}$ & 18 & 22.2 & 15 & 14.4 & & 9 & 9.6 & 16 & 15.5 & \\
\hline$>30\left(\mathrm{BMI}>95^{\text {th }} \mathrm{P}\right)$ & 11 & 13.6 & 7 & 6.7 & & 14 & 14.9 & 5 & 4.9 & \\
\hline
\end{tabular}

\begin{tabular}{|c|c|c|c|c|c|}
\hline \multirow[t]{3}{*}{$\begin{array}{l}\text { Feature } \\
\text { (Variable) }\end{array}$} & \multicolumn{4}{|c|}{$\begin{array}{l}\text { Study group (S) } \\
(n=175)\end{array}$} & \multirow[t]{3}{*}{ Test result } \\
\hline & \multicolumn{2}{|c|}{$\begin{array}{l}\text { Age } \leq 12 \\
(n=81)\end{array}$} & \multicolumn{2}{|c|}{$\begin{array}{l}\text { Age }>12 \\
(n=94)\end{array}$} & \\
\hline & $n$ & $\%$ & $n$ & $\%$ & \\
\hline Asthma & 6 & $7.4 \%$ & 19 & $20.2 \%$ & \multirow{2}{*}{$p=0.028$} \\
\hline No asthma & 75 & $92.6 \%$ & 75 & $79.8 \%$ & \\
\hline
\end{tabular}

3.5 , and the average BMI was $19.6 \pm 3.9$. In the control group (C), the average age was $12.1 \pm 3.6$, and the average BMI was 18.9 \pm 3.5 . Both of the compared groups were uniform as regard gender and age $(p>0.05)$. In group S, BMI was on average greater by $0.4 \mathrm{~kg} / \mathrm{m}^{2}$ in comparison to group $C$, but the difference was not statistically significant $\left(19.1 \mathrm{~kg} / \mathrm{m}^{2}\right.$ vs $\left.18.9 \mathrm{~kg} / \mathrm{m}^{2} ; p=0.123\right)$. However, the proportion of overweight and obese children in study group $S$ was greater than in control group C $(p=0.043)$ (Table 1$)$.

Both study groups were divided into two subgroups: children up to 12 and children over $12(\mathrm{~S} \leq 12, \mathrm{~S}>12, \mathrm{C} \leq 12$ and $\mathrm{C}$ $>12$, respectively.)

In both groups $S$ and $C$, no significant differences were observed in the number of overweight children $(\mathrm{BMI}>25$, above the $85^{\text {th }}$ percentile) between the age subgroups $\leq 12$ and $>12$ (S: $p=0.142, \mathrm{C}: p=0.061$ ). (Table 2 and Figure 1 ).

In the younger group $(\leq 12)$, the percentage of overweight and obese children was higher in group $S$ than in group $C$, but the difference was statistically insignificant $(p=0.150)$. In the older group ( $>12$ ), the percentage of overweight and obese children was insignificantly higher in group $S$ than in group $C$ $(p=0.063)$. A correlation between atopy and body mass in the analyzed age groups was not observed $(p>0.05)$ (Table 3 ).

In group $S$ with the total of 25 children diagnosed with bronchial asthma, 6 children were in group aged $\leq 12(7.4 \%)$ and 19 children were in group aged $>12(20.2 \%)$ the difference was statistically significant $(p=0.028)$ (Table 4 and Figure 2). 


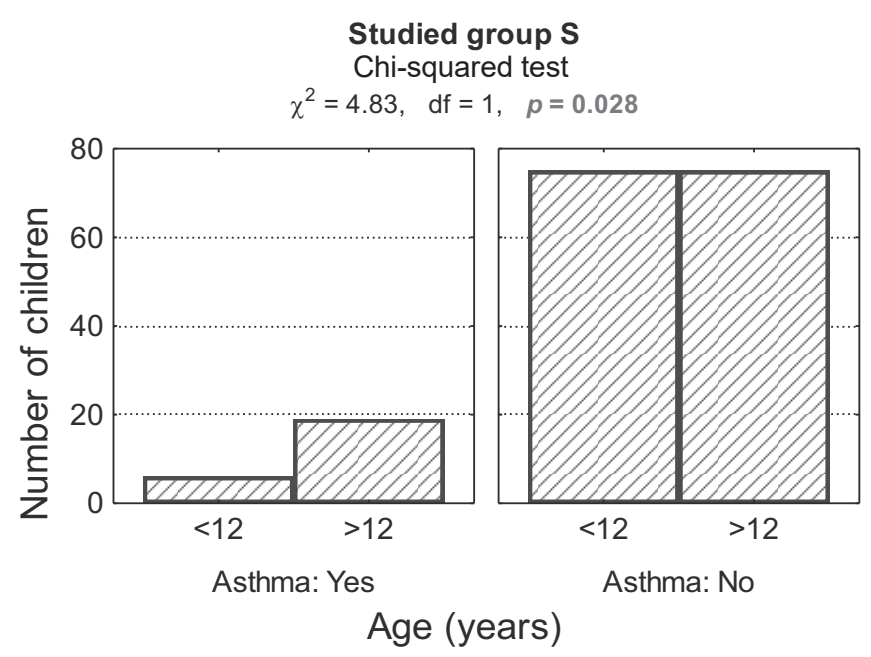

Figure 2. Number of children in subgroups with different age and diagnosed asthma and the result of independence test

Group S - patients with atopy; Asthma: Yes - patient with doctor-diagnosed asthma; $<12$ - children up to 12 years old; $>12$ - children over 12 .

\begin{tabular}{|c|c|c|c|c|c|}
\hline \multirow[t]{3}{*}{ BMI [percentile] } & \multicolumn{4}{|c|}{$\begin{array}{l}\text { Study group (S) } \\
(n=175)\end{array}$} & \multirow[t]{3}{*}{ Test result } \\
\hline & \multicolumn{2}{|c|}{$\begin{array}{l}\text { Asthma } \\
(n=25) \\
\end{array}$} & \multicolumn{2}{|c|}{$\begin{array}{l}\text { No asthma } \\
(n=150)\end{array}$} & \\
\hline & $n$ & $\%$ & $n$ & $\%$ & \\
\hline Underweight $\mathrm{BMI}<5^{\text {th }} \mathrm{P}$ & 0 & 0 & 13 & 8.7 & \multirow{4}{*}{$p<0.001$} \\
\hline Normal range $5^{\text {th }} \mathrm{P} \leq \mathrm{BMI} \leq 85^{\text {th }} \mathrm{P}$ & 0 & 0 & 110 & 73.3 & \\
\hline Overweight $85^{\text {th }} \mathrm{P}<\mathrm{BMI} \leq 95^{\text {th }} \mathrm{P}$ & 7 & 28 & 20 & 13.3 & \\
\hline Obese $>30\left(\mathrm{BMI}>95^{\text {th }} \mathrm{P}\right)$ & 18 & 72 & 7 & 4.7 & \\
\hline
\end{tabular}

Studied group S

Pearson's chi-squared test

$\chi^{2}=91.5, \quad$ df $=3, \quad p<0.001$

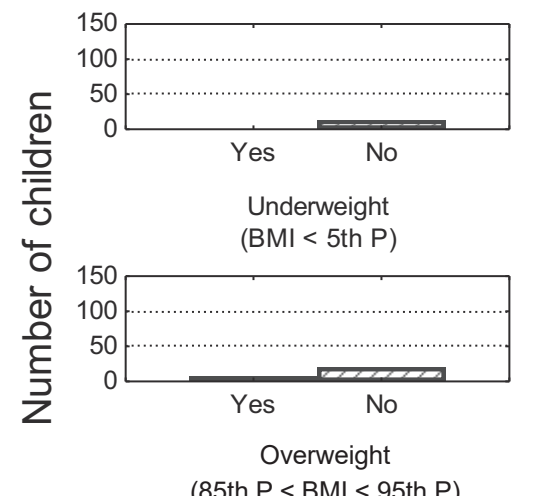

(85th $\mathrm{P}<\mathrm{BMI}<$ 95th $\mathrm{P}$ )

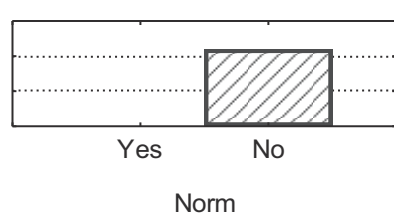

(5th $\mathrm{P}<\mathrm{BMI}<$ 85th $\mathrm{P}$ )

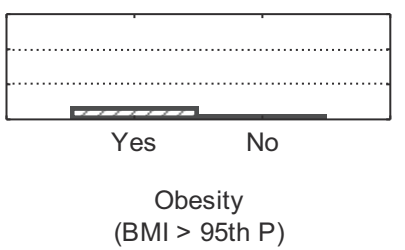

(BMI > 95th P)

Asthma

In group S, there were 148 children with correct body weight, and only 2 of them (1.3\%) were diagnosed with asthma. As many as 23 out of 25 overweight children (92\%) were diagnosed with asthma. In group S, the prevalence of asthma in overweight children (above $85^{\text {th }}$ percentile) was significantly higher in comparison with the group with normal body weight $(p<0.001)$ (Table 5 and Figure 3).

\section{Discussion}

Atopy, a family history of asthma and air pollution are well-recognized risk factors of the development of asthma in children. A growth in the prevalence of overweight and bronchial asthma in children has been observed over the last three decades in developed countries. Obesity in children has become a global problem for public health, especially in developed countries. Statistical data from the USA, Great Britain and Holland demonstrate that the prevalence of overweight children and adolescents remained at the same level (about 20\%) in 1995-2008 [16]. Newer studies from the USA have been less optimistic, and they estimate the prevalence of obesity in children aged $2-9$ at $17 \%$ [17].

The significant growth in the percentage of overweight adolescents aged 12-18 observed in our study compared to children aged $6-12$, along with a growth in the prevalence of asthma in older children, demonstrates that apart from the genetic factors, a change of lifestyle, including diet, lower physical activity, as well as early exposure to various environmental factors, can also affect the development of asthma in children. This is why epigenetic mechanisms can influence the development 
of asthma and obesity [18]. Single studies demonstrate the protective effect of a diet rich in vegetables, fruit and fish during pregnancy on the maturation of the immune and respiratory systems [19]. The influence of gender on the prevalence of asthma in children of incorrect weight is inconclusive. Several papers have published contradictory results [20, 21]. The relationship between overweight and asthma in children is complex and covers both genetic and epigenetic factors, as well as environmental factors (diet, stimulants, physical activity, smoking), the mechanical effect on lung function (small restriction), as well as minimal systemic inflammation (growth in the concentration of interleukin 6 and leptins, increased concentration of adiponectin) [22]. A positive influence of the reduction of body mass on the course of asthma was observed in obese adult patients [23]. The analysis of the correlation between asthma and overweight in the population of children and adolescents in Oleśnica confirms the general trend of connecting the epidemic of asthma and obesity. The growth in the prevalence of overweight and asthma in the studied group aged over 12 in comparison with children aged 6-12 is especially alarming. Overweight in the group aged $12-18$ is probably the result of the limiting of physi- cal activity and adverse eating habits connected with the less strict supervision of a child's diet by parents. The universal introduction of education regarding a healthy lifestyle and proper diet in children and adolescents in Poland is an urgent challenge for doctors and the health care system.

\section{Limitations of the study}

Limitations of this study included the small size of the cohort and the probable underestimation of atopic disorders in the control group. Additionally, BMI in children and adolescents is an imperfect proxy for body fat [24].

\section{Conclusions}

The prevalence of overweight in the studied population of children and adolescents with atopic diseases was higher than among their healthy peers. We thus concluded that atopy and asthma in children aged 6-18 may lead to a higher risk of overweight and obesity in children and adolescents, which needs to be confirm in further studies.

Source of funding: This work was funded by the authors' resources. Conflict of interest: The authors declare no conflict of interests.

\section{References}

1. Akinbami LJ, Moorman JE, Garbe PL, et al. Status of childhood asthma in the United States, 1980-2007. Pediatrics 2009; 123(Suppl. 3): 131-145.

2. Dietz WH. Overweight in childhood and adolescence. N Engl J Med 2004; 350: 855-857.

3. Akinbami LJ, Moormon JE, Bailey C, et al. Trends in asthma prevalence, health care use and mortality in the United States, 2001-2010. NCHS Bata Brief 2012; 94: 1-8.

4. Ogden CL, Flegal KM, Carroll MD, et al. Prevalence and trends in overweight among US children and adolescents, 1999-2000. JAMA 2002; 288(14): 1728-1732.

5. Jarvis D, Chinn S, Potts J, et al. Association of body mass index with respiratory symptoms and atopy: results from the European Community Respiratory Health Survey. Clin Exp Allergy 2002; 32(6): 831-837.

6. Boulet LP. Asthma and obesity. Clin Exp Allergy 2013; 43(1): 8-21.

7. Ogden CL, Flegal KM, Carroll MD, et al. Prevalence and trends in overweight among US children and adolescents, 1999-2000. JAMA 2002; 288(14): 1728-1732.

8. Flaherman V, Rutherford GW. A meta-analysis of the effect of high weight on asthma. Arch Dis Child 2006; 91(4): 334-339.

9. Lu FL, Hsieh CJ, Caffrey JL, et al. Body mass index may modify asthma prevalence among low-birth-weight children. A J Epidemiol 2012; 176(1): 32-42.

10. Rzehak P, Wijga AH, Keil T, et al. Body mass index trajectory classes and incident asthma in childhood: results from 8 European birth cohorts - a Global Allergy and Asthma European Network initiative. J Allergy Clin Immunol 2013; 131(6): 1528-1536.

11. Global Initiative for Asthma. Global strategy for asthma management and prevention. Updated 2015. Available from URL: http://www. ginasthma.org/local/uploads/files/GINA, Report 2015.pdf.

12. Derezinski T, Wolf J, Szyndler A, et al. Comparison of incident hypertension, overweight and obesity in s representative polish junior high-school population in 2005 vs 2014. J Hypertens 2015; 33(Suppl. 1): e35.

13. UNICEF Office of Research (2013). Child Well-being in Rich Countries: a comparative overview. Innocenti Report Card 11, UNICEF Office of Research, Florence [cited 20.04.2017]. Available from URL: www.unicef-irc.org/publications/pdf/rc11_eng.pdf.

14. Heinzerling L, Mari A, Bergmann KC, et al. The skin prick test - European standards. Clin Trans/ Allergy 2013; 3(1): 3, doi: 10.1186/20457022-3-3.

15. Palczewska I, Niedźwiecka Z. Wskaźniki rozwoju somatycznego dzieci i młodzieży warszawskiej. Med Wieku Rozw 2001; 5(Supl. I, nr 2): 1-120 (in Polish).

16. Olds T, Maher C, Zumin S, et al. Evidence that the prevalence of childhood overweight is plateauing: data from nine countries. Int $J$ Pediatr Obes 2011; 6(5-6): 342-360.

17. Ogden CL, Carroll MD, Kit BK, et al. Prevalence of childhood and adult obesity in the United States, 2011-2012. JAMA 2014; 311(8): 806-814.

18. Permaul P, Kanchogkittiphon W, Phipatanakul W. Childhood asthma and obesity - what is the true link? Ann Allergy Asthma Immunol 2014; 113(3): 244-246.

19. Willers SM, Wijga AH, Brunekreef B, et al. Maternal food consumption during pregnancy and the longitudinal development of childhood asthma. A J Respir Crit Care Med 2008; 178(2): 124-131.

20. Castro-Rodriguez JA, Holberg CJ, Morgan WJ, et al. Increased incidence of asthma-like symptoms in girls who become overweight or obese during the school years. Am J Respir Crit Care Med 2001; 163(6): 1344-1349.

21. Figueroa-Muñoz JI, Chinn S, Rona RJ. Association between obesity and asthma in 4-11 year old children in the UK. Thorax 2001; 56(2): 133-137.

22. Kattan M, Kumar R, Bloomberg GR, et al. Asthma control, adiposity, and adipokines among innercity adolescents. J Allergy Clin Immunol 2010; 125(3): 584-592.

23. Juel CT, Ali Z, Nilas L, et al. Asthma and obesity: does weight loss improve asthma control? A systematic review. J Asthma Allergy 2012; 5: 21-26. 
24. Maynard LM, Wisemandle W, Roche AF, et al. Childhood body composition in relation to body mass index. Pediatrics 2001; 107(2): 344-350.

Tables: 5

Figures: 3

References: 24

Received: 26.04 .2017

Revised: 06.07.2017

Accepted: 21.07.2017

Address for correspondence:

Krzysztof Wytrychowski, MD, PhD

Katedra i Klinika Chorób Wewnętrznych i Alergologii UM

ul. Skłodowskiej-Curie 66

50-369 Wrocław

Polska

Tel.: +48 71 784-25-21

E-mail: krzysztof.wytrychowski@umed.wroc.pl 